\title{
ELECTRONIC WAREHOUSE RECEIPTS REGISTRY AS A STEP FROM PAPER TO ELECTRONIC WAREHOUSE RECEIPTS ${ }^{1}$
}

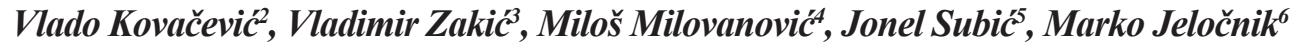

\begin{abstract}
The aim of this paper is to determine the economic viability of the electronic warehouse receipt registry introduction, as a step toward electronic warehouse receipts.

Both forms of warehouse receipt paper and electronic exist in practice, but paper warehouse receipts are more widespread. In this paper, the dematerialization process is analysed in two steps. The first step is the dematerialization of warehouse receipt registry, with warehouse receipts still in paper form. The second step is the introduction of electronic warehouse receipts themselves. Dematerialization of warehouse receipts is more complex than that for financial securities, because of the individual characteristics of each warehouse receipt. As a consequence, electronic warehouse receipts are in place for only to a handful of commodities, namely cotton and a few grains. Nevertheless, the movement towards the electronic warehouse receipt, which began several decades ago with financial securities, is now taking hold in the agricultural sector.
\end{abstract}

In this paper is analysed Serbian electronic registry, since the Serbia is first country in EU with electronic warehouse receipts registry donated by FAO. Performed analysis shows the considerable impact of electronic warehouse receipts registry establishment on enhancing the security of the system of public warehouses, and on advancing the trade with warehouse receipt.

1 Paper is a part of project III 46006, funded by Ministry of Education, Science and Technological Development of Republic of Serbia, for the project period 2011-2015.

2 Vlado Kovačević, Ph.D., Research Associate, Minister Adviser, Ministry of Agriculture and Environmental Protection of the Republic of Serbia, Nemanjina Street no. 22-26, 11000 Belgrade, Serbia, Phone: +381 646581 519, E-mail: vlado.kovacevic@minpolj.gov.rs

3 Vladimir Zakić, Ph.D., Assistant Professor, University of Belgrade, Faculty of Agriculture, Nemanjina Street no. 6, 11080 Zemun, Serbia, Phone: +381 63313 234, E-mail: zakic@agrif.bg.ac.rs

4 Miloš Milovanović, M.Sc., Coordinator of FAO-EBRD projects in the Republic of Serbia, Todora Dukina Street no. 29, 11000 Belgrade, Phone: +381 64823 56 28, E-mail: milos.milovanovic@fao.org

5 Jonel Subić, Ph.D., Senior Research Associate, Associate Professor, Institute of Agricultural Economics, Volgina Street no. 15, 11060 Belgrade, Serbia, Phone: +381 63296 111, E-mail: jonel s@iep.bg.ac.rs

6 Marko Jeločnik, M.A., Research Assistant, Institute of Agricultural Economics, Volgina Street no. 15, 11060 Belgrade, Serbia, Phone: +381 116972 858, E-mail: marko j@iep.bg.ac.rs

EP 2016 (63) 3 (801-815) 
Key words: commodity exchange, public warehouse, electronic warehouse receipt, short term loans.

JEL: $Q 13, Q 14, G 18$.

\section{Introduction}

The common questions in countries without public warehouses systems are: Is the public warehouse system needed? Is it necessary to establish public warehouse system with all three components (licensing procedure, Indemnity Fund and special inspection service)? Should the public warehouse system be embedded in the legislation or contractual relations between the interested parties are sufficient? Is it useful to establish an electronic warehouse receipts (EWR)?

An appropriate legal framework is a prerequisite for a functioning public warehouse system (IFC/WB, 2013). Although public warehouse system is possible even in poor legal environments, in such conditions transaction costs are higher and bank credit committees will be more reticent to approve transactions. Bank risk controllers and credit committees in particular feel more comfortable when there is strong legislation in place protecting the integrity of the system, establishing clear procedures in case of bankruptcy and default, and allowing the perfection of security interests (Zakić et al., 2014).

There were several attempts to create private public warehouse systems, like in Russia, Kazakhstan and Turkey, mostly from banks and commodity exchanges, but without success (Belozertsov et al., 2011). Recommendation can be given that public warehouse system has to be established through national legislation, while licensing and controlling function has to be done by government.

The public warehouse system is based on the licensing of warehouses for grains and oilseeds. To obtain a license, a warehouse must meet the requirements in terms of equipment and facilities and show positive business performance in the previous accounting period, including a sufficient level of a free capital (Law on public warehouses for agricultural products, 2009). A public warehouse may issue a warehouse receipt for its own stored commodity or for the commodity of a third party, as proof of storage (Zakić et al., 2014). ${ }^{7}$

The experience of USA, Canada, majority of EU countries, Ukraine, Serbia, etc., shows that fully functional warehouse receipts system is very beneficial for the agribusiness sector.

The warehouse receipts systems with all the supporting structures in place have been proven in practice to be more efficient compared with partly established systems (Hollinger, Rutten, 2009). If possible, countries opting for establishment of the system should have: 1) Licensing body and licensing procedures for warehouses in order to obtain public warehouses license; 2) Special inspection body in charge of controlling public warehouses; 3) Guarantee structure

7 In many warehouse systems, public warehouses are prohibited of issuing warehouse receipts for their own commodity. Serbia is allowing this action and this can be recommended for all other systems. 
(such as Indemnity Fund(IF)) needs to be established to reimburse the grain owners/warehouse receipts holder if public warehouse cannot deliver grain to the owner. It is important to have out-of-court procedure for compensation.

If the system is not based on all three components, like it was in the case of Romania, players in the system will not have enough confidence when landing against warehouse receipts. As a consequence banks will be reluctant or interest rate will be higher, traders will have doubt that the grain will be delivered from warehouses and avoid trading with warehouse receipts, etc. (Mahanta, 2012). Development of warehouse receipts is also an essential base for futures and option markets, because warehouse receipts are needed for futures contracts delivery (Coulter, Onumah, 2002).

The warehouse receipt can be used as pledge for short-term loans, which typically have a lower interest rate compared to other short-term loans. The warehouse receipt can be traded and typically generate higher prices than the same product sold with other proof of storage (Giovannucci et al., 2000).

Besides being the pledge for short-term loans, warehouse receipt could also be used for repurchase agreement. Repurchase agreement is an agreement on the sale of securities with a commitment to repurchase them at a specified period and at a fixed price (Mirović, Bolesnikov, 2013). The seller of warehouse receipt (farmer) agrees to repurchase them from the buyer (bank) in predefined period and price.

The benefits of warehouse receipts such as a higher price for commodity stored in a public warehouse and the acceptance as pledge by commercial banks are the result of the confidence that banks and traders have in the system. This confidence is derived from so-called "Three rounds of safety" that are built into the system, i.e.: 1) only a first class warehouse with appropriate financial indicators and equipment can be licensed; 2) a special inspection service monitors the commodities stored in public warehouses; 3) Indemnity Fund, in situation when the owner of the commodity cannot get out the products from the public warehouse, has to indemnify the owner within five days through an out-of-court procedure.

One of the milestones of the public warehouse system is the fact that the Indemnity Fund has separate funds intended for compensation to owners of different types of products (Vasiljević, Zakić, 2006).

A warehouse receipt system can (Varangis, Larson, 1996): a) improve farm income and smooth domestic prices by providing an instrument to farmers to spread sales throughout the crop year; b) mobilize credit to agriculture by creating a secure collateral for banks; c) help create cash and forward markets and thus enhance price discovery and competition; d) provide a way to gradually reduce the role of government in agricultural commercialization; e) combine with price hedging instruments to predetermine the cost of future purchases or sales. 


\section{The warehouse receipt and warehouse receipt registry}

Warehouse receipts (WR) are commodity securities (which can be in paper or electronic form) issued by a warehouse operator that proves that the commodity has been stored. The warehouse receipts prove ownership of the commodity and the warehouse's obligation to deliver the commodity to the legitimate holder of the receipt (Mor, Fernandes, 2009).

The physical (paper) warehouse receipt may consist of either one or two parts.

In the United States, the warehouse receipt is a single document. Two-part receipts are more common in continental Europe and Latin America, and have also been adopted elsewhere. Two-part receipts allowing trading on both commodity and pledge market: one of the parts is related to the ownership of the commodity, and the other to the pledge. Choice of the most appropriate type of warehouse receipt should be based on an evaluation of the situation in each country. A single-part receipt is simpler and more convenient tool for commercial transactions (USAID, 2002).

The warehouse receipt in paper form should be protected against fraud. The system should develop a reliable mechanism for keeping track of warehouse receipts both at the licensed warehouse level and for the overall system usually by sending regular periodical reports from each public warehouse to system administrator. Information on warehouse receipts in paper form is stored in central electronic register of warehouse receipts (Hollinger, Rutten, 2009).

Securities such as shares and bonds are in dematerialized form in many countries, commodity securities such as warehouse receipts are rarely in dematerialized form because of its individual characteristic dematerialization is more complex (Vasiljević et al., 2014).

The movement from paper to electronic warehouse receipt is relatively recent. Even today in the USA only cotton is fully operational in an electronic format, with several grains participating under a Department of Agriculture trial system. Still, even under this trial system, Electronic warehouse receipts (EWRs) are being used in a manner that was unheard of only 20 years ago. Thus, EWRs in these programs can be used as: pledge for loans through approved providers with financial lending institutions; for intra-company transactions to reposition grain to another approved warehouse; as pledge to meet margin or other financial requirements at futures exchanges; for transferring ownership to commodities between different warehouses, processors, ethanol plants and end users; and to transfer ownership to grains and oilseeds through the delivery process at futures exchanges.

The U.S. cotton industry set up an electronic cotton warehouse receipts in 1993. Led by Plains Cotton Cooperative Association of Lubbock, Texas, which was issued a patent for an electronic title system, and the National Cotton Council, the cotton industry pushed for electronic warehouse receipts as a means to introduce significant efficiencies into an antiquated system of handling commodity sales transactions. The structure envisioned by the cotton industry was one in which the Secretary of Agriculture would establish standards that would govern so-called "system providers." These providers would maintain a computer system as required by the secretary. Individual warehouses would 
then contract with the system providers in order to use electronic warehouse receipts for cotton (USAID, 2011).

As example South Africa's Electronic Silo Certificates system keeps the whole process, from issuance to trade and pledging, in an electronic format. Certified warehouses enter information on stored commodity in an electronic database. The database serves as a basis for exchange delivery systems, as well as for lending against warehouse receipt. Banks has possibilities to enter pledge on warehouse receipt directly into the system, trading of dematerialized warehouse receipts (as an interface with traders and investors) and information supply (to clients, government agencies, etc.).

In the Western Europe, central registers for warehouse receipts are not common. Commodity exchanges generally have their own registers to ensure an efficient delivery mechanism. Nevertheless, it would be advisable for ECA countries to set up a registers. Doing so is not costly, and registers provide a significant level of protection against risks of fraud (Gashayie, Singh, 2015).

One positive example is Ukraine's Central electronic warehouse receipt register, which uses software to keep track of the receipts (which are still issued in paper form) and to perform various regulatory and control functions (Hollinger, Rutten, 2009). Advantages of electronic warehouse receipts vs. paper warehouse receipts are:

- Electronic system is safer because public warehouse will be allowed to issue warehouse receipts up to the licensed capacity (electronic system will stop issuing the warehouse receipt for any quantity over the licensed capacity), while in paper form public warehouse can issue warehouse receipts in quantity greater than the licensed capacity. In this manner, the electronic system would increase the overall safety and the lower needed amount of funds in the Indemnity Fund;

- Electronic warehouse system is secured from fraud and forgery. As the information resides on the central database it is not possible to make duplicate or use an outdated receipts;

- It also breaks all the geographical barriers as the physical production and exchange of documents not needed. The seller can transfer electronic warehouse receipt to the buyer and transaction completes when the buyer confirms it;

- Electronic warehouse receipt can be split and this fractionalization can be done in instant;

- Electronic warehouse receipts can supplement e-business as the buyer can be sure in quality and quantity of offered product;

- Inspection service in charge of inspecting public warehouse system is in position to follow in real time status of commodity in each public warehouses instead of relying on periodical reports from public warehouses;

- There is no need for public warehouse to purchase blank paper warehouses receipts forms and registries for keeping public warehouse receipts records, so the overall system would be less expensive;

- Reports on warehouse receipts issuance, trade with warehouse receipts, loans against 
warehouse receipts can be easily derived from electronic system for purpose of analytics, i.e. for different kind of subsidies of public warehouses systems indicators as number of new warehouses, change in overall licensed capacity, data on loans, etc.

Scheme 1. Electronic registry for warehouse receipts (Design of FAO/Ministry of Agriculture and Environmental Protection of the Republic of Serbia)

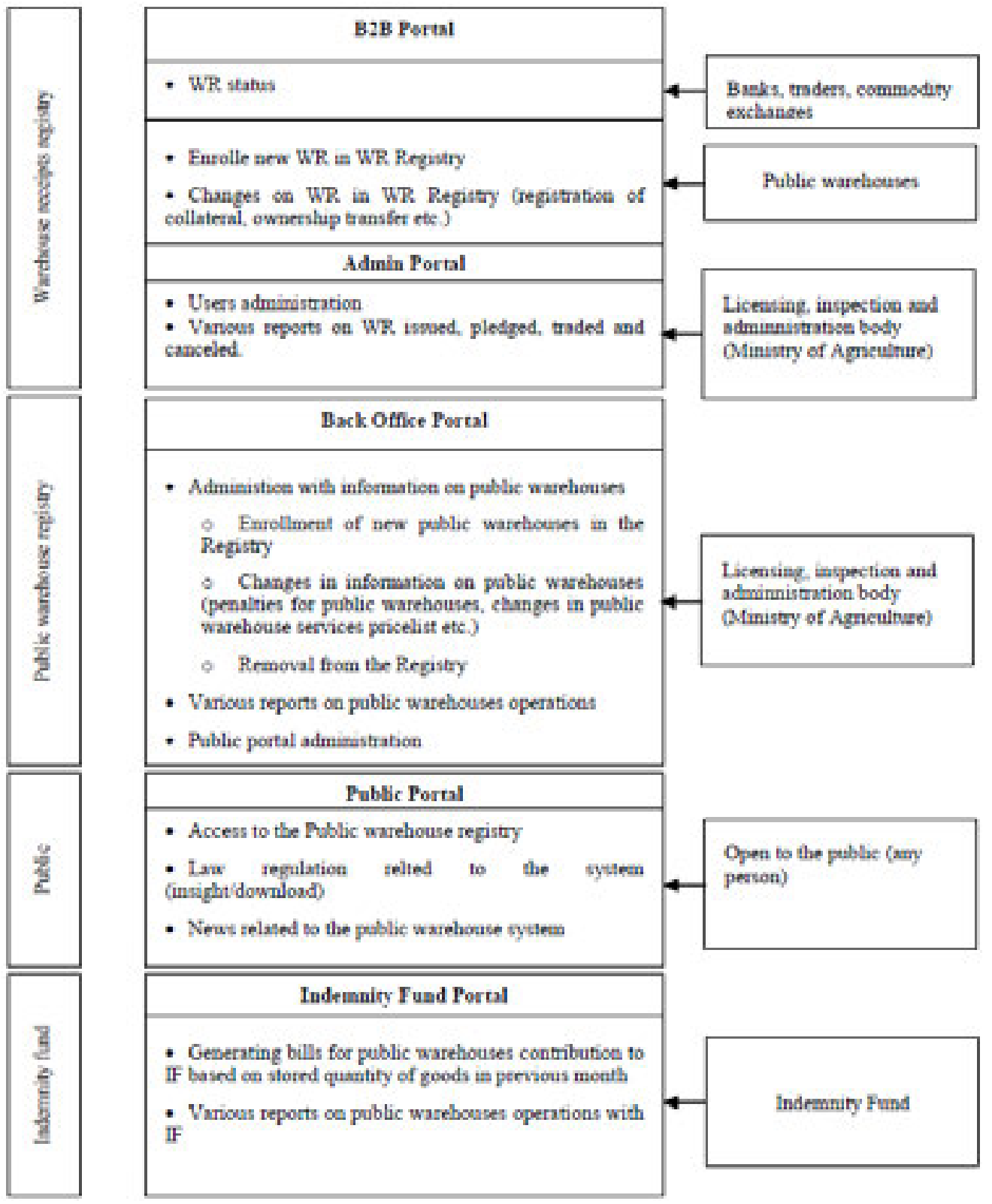

Source: Authors' interpretation of established electronic registry. 
Ministry of Agriculture and Environmental Protection of the Republic of Serbia, was develop Electronic registry for warehouse receipts with FAO support and supervision. This Registry is in the testing faze by all participants in the public warehouse system and it is expected to enter in the work (Jovičić et al., 2014).

Registry is planned to be introduced gradually, public warehouses with good internet access, will be transferred from paper evidence of warehouse receipts (WR) to electronic while other with not sufficient capacities will continue to work in paper WR evidence until requirements for electronic Registry are met. $^{8}$

Registry is designed to improve public warehouse system by increasing system transparency. This electronic warehouse receipts is designed with possibility to be upgraded to electronic warehouse receipts system (Shamos, 2004).

Electronic registry is allowing public warehouse and other participants to gain experience in operating in electronic system before electronic warehouse receipts (EWR) system implementation.

According to Scheme 1., banks, traders, commodity exchanges will have possibility to observe the warehouse receipts (WR) status in WR Registry. Public warehouses will still operate with paper form of warehouse receipts, but they will enrolled all information on new opened WR and changes in warehouse receipts status in WR Registry which will automatically prevent opening WR in quantity greater than licensed capacity.

In the Back office portal licensing, inspection and administration body will be able to automatically generate various kinds of reports on public warehouses and warehouse receipts. In paper warehouse receipts system public warehouses are sending information on WR issued, pledged and cancelled in usually two weeks period by e-mail or fax, and operator needs to enrol this information in database manually (Zakić, Kovačević, 2012). Public portal is open to the public where the goods owners can access public warehouse registry to check closest public warehouse to store goods, have insight in public warehouses services pricelists, etc. Warehouses may download all forms for licensing procedures, manuals, etc.

Indemnity fund (IF) portal is automatically generating bills for public warehouses which they are obliged to contribute to IF on monthly basis, based on quantity of stored products. In paper warehouse receipts system public warehouses are calculating this contribution which is time consuming and there is possibility of mistake.

\section{Methodology and data sources}

In this paper is analysed system of: Paper warehouse receipts; Electronic warehouse receipts registry; and Full electronic warehouse receipts.

Analysis is performed by questionnaire submitted by next participants in the pubic warehouse

8 Important is to be fully transferred to electronic Registry. Situation to use both paper and electronic warehouse receipts (WR) registry is not allowed.

EP 2016 (63) 3 (801-815) 
system: banks ( 5 commercial banks actively engaged in lending against warehouse receipts; 5 public warehouses; 5 warehouse receipts owners; licensing, inspection and administration body (Ministry of Agriculture and Environmental Protection); Indemnity Fund; Commodity Exchange - Novi Sad.

Participants in survey are rating this three warehouse systems by 1 to 5 marks. Mark 1 represents lower importance, while mark 5 is high importance. Questionnaire was conducted in the period of $25^{\text {th }}$ May to $3^{\text {rd }}$ September 2014. Beside mentioned, in paper writing are used all available scientific papers and relevant public documents focused on observed topic.

\section{Results and discussion}

Paper warehouse receipts (WR) system

Average mark for paper warehouse receipts system from banks are moderate $(2,8)$, as a result of extensive procedures and increased risk when lending against warehouse receipts. After providing loans against warehouse receipts, a bank: 1) writes information on the pledge on the warehouse receipt; 2) sends information on the pledge and a copy of the warehouse receipt to the public warehouse that issued the warehouse receipt for the public warehouse to record the pledge in the register of warehouse receipt; 3) keeps the warehouse receipt until the debt is paid. It is time consuming procedure and carries an additional risk for lender.

Graph 1. Paper warehouse receipts (WR) system rating

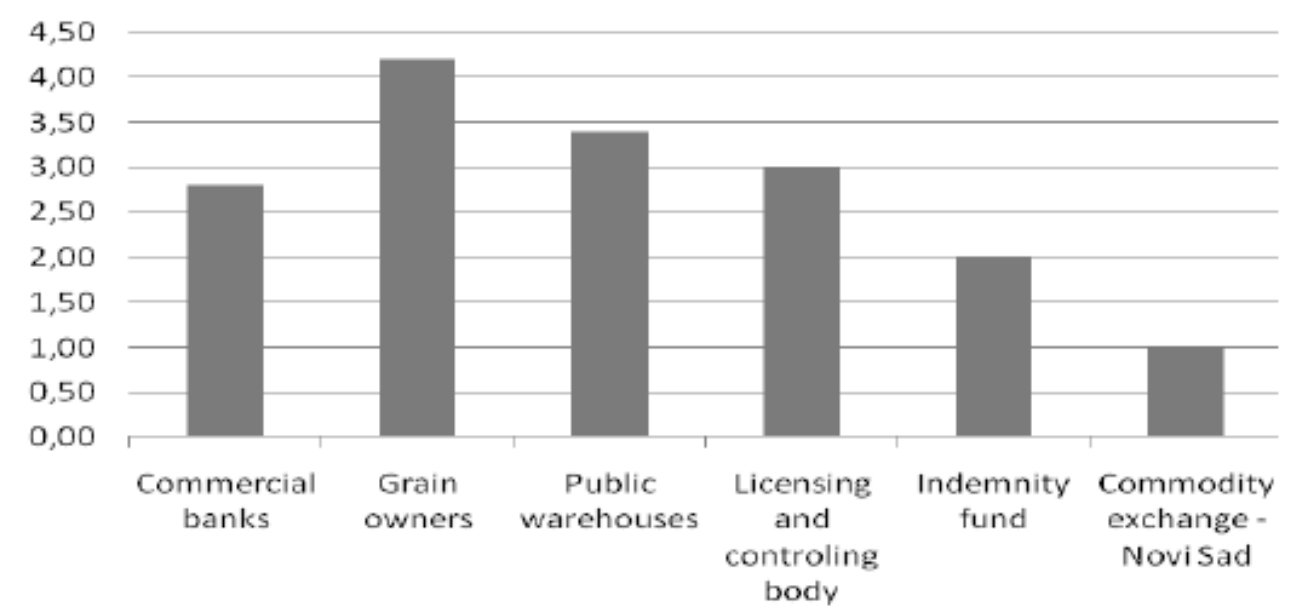

Source: Kovačević et al., 2014

Grain owners are rated paper warehouse receipts system with average mark 4,2 what can be explained by broad acceptance and low interest rate on warehouse receipts' loans in Serbia. Communication in the case of the paper warehouse receipts system is slow, and based on periodical reports from each public warehouse to the public warehouse management system. In case of fraud by a public warehouse, the inspection service cannot immediately prevent the issue of warehouse receipt. Informing warehouse receipt owners or lenders against warehouse 
receipts is based on tracking a web page or exchange of information in written or oral form. Slow communication and existing high risk level is reason for moderate average mark for paper warehouse receipts system from Ministry of Agriculture and Indemnity fund.

Lowest rate for paper warehouse receipts system is given form Commodity exchange, because of complicated procedure when trading with warehouse receipts which needs to be sent to exchange together with trading order, if the warehouse receipts is sold it will be sent to the buyer, and if not, it will be returned to the owner. The buyer and seller of a warehouse receipt fill the data on trade and need to sign warehouse receipts. The buyer is obliged to provide data on the trade immediately to the public warehouse that issued the warehouse receipt so that it may enter the data in its register of warehouse receipt. This is complicated procedures and warehouse receipts needs to circulate between exchange and traders which increase a risk of losing warehouse receipts and increases transaction costs.

\section{Public warehouse system with electronic register of warehouse receipts}

In the system of electronic warehouse receipts (EWR) register, the warehouse receipt itself is still in paper form, while the evidence on warehouse receipts is electronic. This system offers many advantages over the previous one. Sending data on warehouse receipt is unnecessary, as the administrator and inspection services in the public warehouse system have direct access to the electronic register of warehouse receipt and can generate a range of reports for each public warehouse. The volume of work for the public warehouse and its administrator is thus reduced, as there is no need for the administrator to send reports or enter them. Security in the public warehouse system is improved, since in case of fraudulent behaviour in the public warehouse, the inspection service can immediately prevent the issue of warehouse receipt. ${ }^{9}$ Furthermore, the public warehouse may issue warehouse receipt only for the quantity of commodity for which it is licensed ${ }^{10}$. The electronic register also reduces the public warehouse costs to a small extent since it no longer needs to procure paper diaries for warehouse receipt. All those factors resulted in better rating than the paper warehouse receipts system from commercial banks, Ministry of Agriculture and Indemnity Fund.

In this system, a bank issues a loan against a warehouse receipt in the same way as in the allpaper system, in other words, it records the credit data on the paper and sends the information to the issuing public warehouse. The advantage of the system of electronic registers is that the bank can see the evidence of ownership of the warehouse receipts and any encumbrance on the warehouse receipts directly in the electronic register, and after sending information on pledges on the warehouse receipts can check the warehouse receipts in the register to see whether the public warehouse has correctly entered the data sent. Increasing the security in

9 In contrast to the completely electronic warehouse receipts system, the public warehouse still possesses the WRs and can still issue receipts until the inspectors arrive at the warehouse, but cannot enter them into the register. A banker or dealer must be trained to check whether the record is entered into the electronic register before buying it or lending against it.

10 The electronic system prevents the issue of commodity records that surpass the licensed capacity of the public warehouse.

EP 2016 (63) 3 (801-815) 
the electronic warehouse receipts system in this way has a positive impact on lending against warehouse receipts.

Graph 2. Public warehouse system with electronic register of warehouse receipts rating

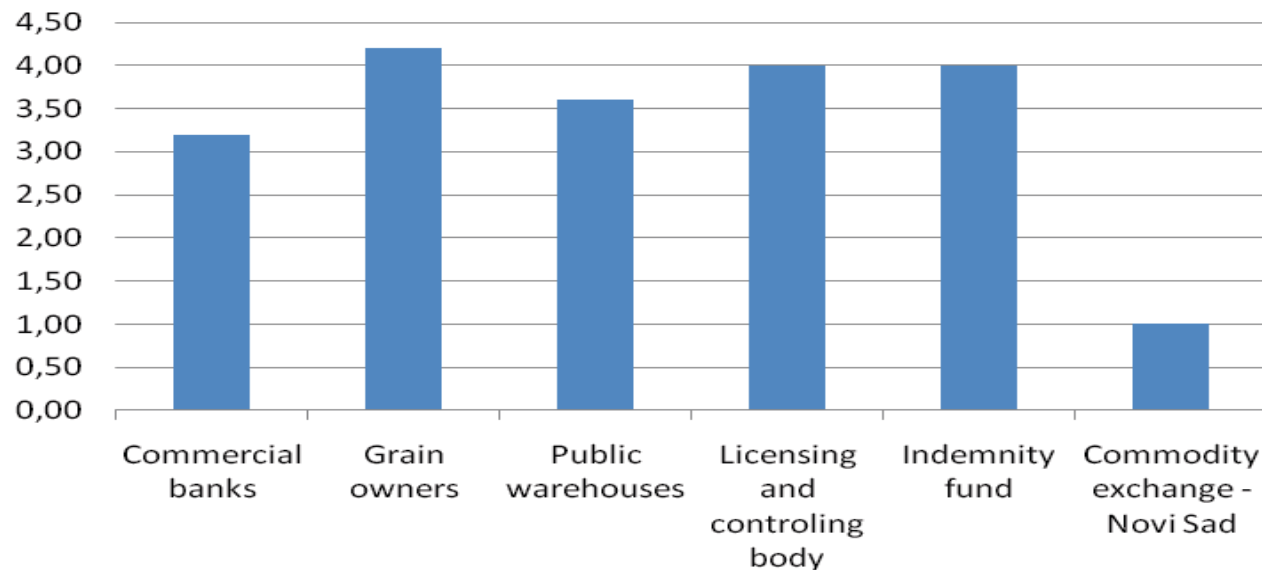

Source: Kovačević et al., 2014.

Buyer and seller of warehouse receipt enter the trade data and sign the warehouse receipt just as in the all-paper system. The advantage of the electronic warehouse receipts (EWR) register lies in the buyer being able to see information on the ownership of the WR and any encumbrance on the warehouse receipts (WR) directly in the electronic register, and after sending the information on trade with WR can check the warehouse receipts in the register to see whether the public warehouse has entered the data correctly as sent. Increasing the security in the electronic WR system in this way has a positive impact on lending against warehouse receipts. Survey shows that warehouse receipts' owners are not seeing benefits from electronic WR registry, same as Commodity exchange because of need for operation with complicated and risky procedures with warehouse receipts exist.

\section{Electronic warehouse receipts system}

In the Graph 3. is shown rating of the electronic warehouse receipts. Banks will be allowed to access the electronic warehouse system and enter pledge at the warehouse when lending against a warehouse receipt. The procedure for banks is less time consuming (for receipts in paper form banks need to send a query to the warehouse by fax and, when the pledge is established, again need to fax the warehouse to inform it that pledge is established on the warehouse receipt, etc.) and more secure, leading to lower interest rates.

In case of fraud by the public warehouse the inspection service can immediately block the issue of warehouse receipt. The electronic system automatically prevents the public warehouse from issuing warehouse receipt for the complete quantity of products that surpass the licensed capacity of the public warehouse. It also reduces the possibility of errors in issuing warehouse receipt since the system automatically warns of errors, which increases the overall security of the system. The inspection services responsible for monitoring the public warehouse 
may stop further issue of warehouse receipt by the warehouse until they complete checks. Information to the system administrator and inspection is carried out with automatic insight into the system, and the public warehouse does not have to send a report. Increased in safety and procedures lead that banks, Ministry of Agriculture, Indemnity Fund and Commodity Exchange rated the Electronic warehouse receipts (EWR) system with highest rate.

The public warehouse's costs are reduced as there is no need to purchase blank warehouse receipts and register diaries.

Graph 3. Electronic warehouse receipts (EWR) system rating

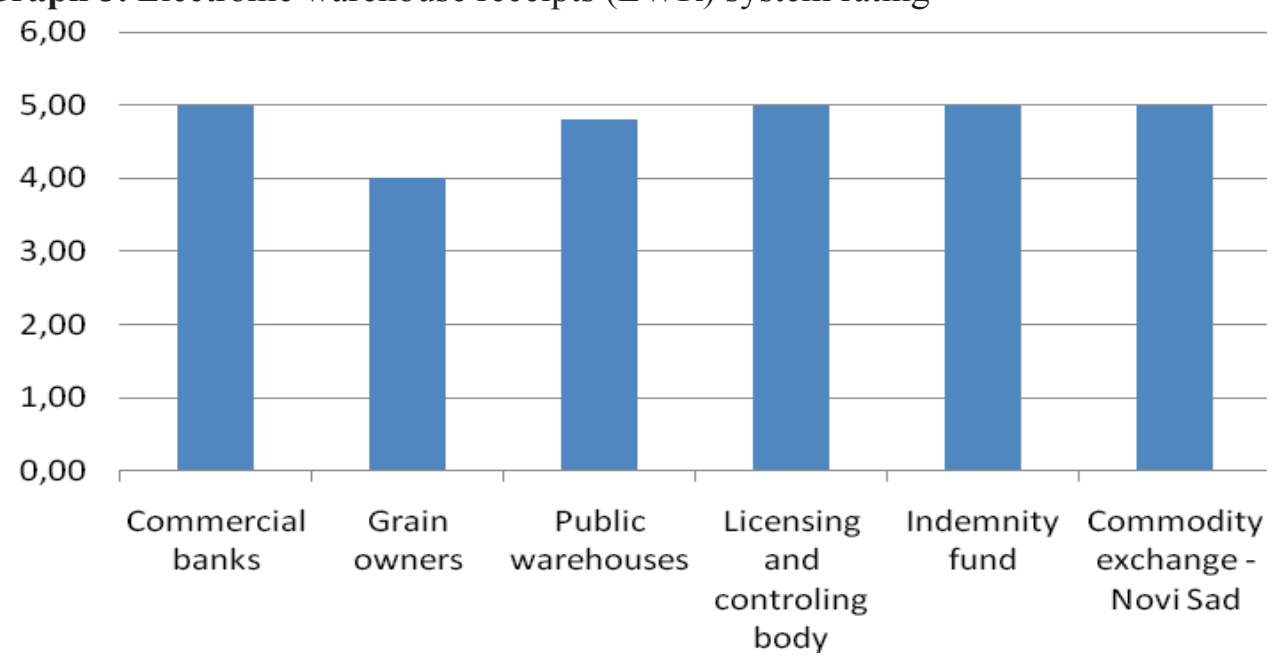

Source: Kovačević et al., 2014.

\section{Trade with warehouse receipts in an electronic warehouse world}

Buyer and seller of warehouse receipt enter data on the trade and sign the warehouse receipt. The buyer is obliged without delay to deliver the data on the transaction to the pubic warehouse that issued the warehouse receipt, so that it can enter the new ownership data into the register of warehouse receipts.

Commodity exchanges will have direct links, and trading orders may be sent in electronic form. Paper warehouse receipts need to be sent to the commodity exchange by post. In the case of electronic warehouse receipts, a trading order can be submitted to local brokerage firms.

\section{Conclusion}

On the basis of this research, it may be concluded that warehouse receipts play an important role in the agribusiness sector, above all because they assure a greater security of warehousing, they make possible delayed sale in that sale takes place not from the sack but rather by the warehouse receipt being used as pledge for credit with the commodity actually being sold later in the year when the price is usually higher, and because commodity are stored in regulated public warehouses rather than unregulated private warehouses, as is often the case now. 
Finally, the research results underlining the great significance of the public warehouse system for agriculture financing. For the development or improvement of the existing public warehouse system, several recommendations can be made:

- Establishment of the public warehouse with all three components: licensing procedures, inspection body and indemnity fund;

- Development of the public warehouse system uniquely for agricultural products Public warehouse system for industrial products must be established separately;

- The system must be based on legislation, rather than on private contracts among its parties;

- The system should be developed in cooperation with the National Bank, to provide the best credit rating for loans against warehouse receipts;

- It is of great importance to introduce electronic warehouse receipts.

Paper warehouse receipt system has the simplest model of the public warehouse. As a disadvantage this system requires long procedures and has a highest risk because of low transparency compared to other two public warehouse systems.

Introducing electronic warehouse receipt register has a positive effect on the administration of the public warehouse system, since there is no need to receive and consolidate regular periodic reports sent by the public warehouse, saving time and staff resources among warehouse operators and administrative employees. The security of the system is also enhanced since the inspection services have direct access to the electronic register of each public warehouse and can rapidly react or prevent the issue of warehouse receipt by a public warehouse. Improving the overall security of the system and insight into the electronic register and the status of each warehouse receipt, even with the same procedure for entering credit on each warehouse receipt has a positive impact on lending against warehouse receipts. In the case of trading in warehouse receipts too, even if the trade is entered on the warehouse receipt itself by the same procedure as in the paper system of warehouse receipts, the improvement of overall system security and the possibility of viewing the electronic register for the status of each warehouse receipt has a positive impact on lending against warehouse receipts. The operating costs of the public warehouse are also reduced since there is no need for purchasing neither blank warehouse receipts forms, nor register diaries, as in the saving of public warehouse staff time needed for purchase and collecting warehouse receipts and registries.

The fully electronic system of warehouse receipt offers the best way of administering the public warehouse system. As in the previous case there is no need to send regular periodical reports to the public warehouse administrator, and the time of warehouse operators and administrators is saved. The security of the system is at the highest level since the electronic system prevents the issue of warehouse receipt above the licensed capacity, and in the case of suspicious operations of a public warehouse the inspection services can halt the issue of warehouse receipt by the public warehouse, while it investigates the facts. Issuing credit is simplified as the banks have access to add pledges to the warehouse receipt themselves, shortening procedures and improving security when lending against warehouse receipts. Trade of warehouse receipt outside the exchanges may be made by directly changing ownership, 
simplifying the procedure. The positive impact mentioned on commodity exchange trading of electronic warehouse receipts occurs through commodity exchanges having direct access and the ability to enter ownership data after trading. The second positive effect of electronic warehouse receipts is the possibility for trading orders to be sent in electronic form. Paper warehouse receipts need to be sent to the commodity exchange by post. Trading orders in the case of electronic warehouse receipts can be submitted via local brokerage firms.

Based on previously mentioned, it may be concluded that the introduction of electronic warehouse receipt has a positive effect on the entire agribusiness sector. Considering the complexity of introducing the electronic system, a two-step introduction may be recommended, whereby electronic registers of warehouse receipt are introduced first, which is simpler and bears a lesser risk of system collapse compared to an electronic warehouse receipt system and in which public warehouses, administrators, inspections, banks and traders may gain experience in preparation for working in a fully electronic system of warehouse receipt.

\section{References}

1. Belozertsov, A., Rutten, L., Hollinger, F. (2011): Commodity exchange in Europe and Central Asia: A means of management of price risk, working paper No. 5, FAO/World Bank, FAO Investment Centre, Rome, p. 88, available at: www.fao.org/3/a-at655e.pdf

2. Coulter, J., Onumah, G. (2002): The role of warehouse receipt systems in enhanced commodity marketing and rural livelihoods in Africa, Food Policy, Vol. 27, No. 2, pp. 319-337.

3. Gashayie, A., Singh, M. (2015): Agricultural finance constraints and innovative models experience for Ethiopia: Empirical evidence from developing countries, Research Journal of Finance and Accounting, Vol. 6, No. 7, pp. 39-49.

4. Giovannucci, D., Varangis, P., Larson, D. (2000): Warehouse receipts: Facilitating credit and commodity markets, in: A guide to developing agricultural markets and agro-enterprises (Giovannucci, D. (edt)), multivolume online database, World Bank, Washington DC, USA, doc. No. 40122, pp. 1-8, available at: www-wds.worldbank.org/external/default/ WDSContentServer/WDSP/IB/2007/07/10/000090341_20070710160223/Rendered/ PDF/401220Warehouse1Receipts01PUBLIC1.pdf

5. Hollinger, F., Rutten, L. (2009): The use of warehouse receipt finance in agriculture in ECA countries, FAO-World Bank Cooperative Programme and FAO - EBRD Cooperative Programme, technical background paper, World Grain Forum 2009, St. Petersburg, Russian Federation, p. 50, available at: www.eastagri.org/files/FAO EBRD-WarehouseReceipt-Financing.pdf

6. IFC/WB (2013): Warehouse finance and warehouse receipt systems: A guide for financial institutions in emerging economies, International Finance Corporation, World Bank Group, Washington, D.C., USA, p. 132, available at: www.mongolbank.mn/conference/ books/01.pdf, accessed: 6.4.2015.

7. Jovičić, D., Jeremić, L., Milićević, L., Zeremski, A. (2014): Warehouse receipts functioning to reduce market risk, Economics of Agriculture, Vol. 61, No. 2, pp. 347-365. 
8. Kovačević, V., Zakić, V., Milovanović, M., Subić, J., Jeločnik, M. (2014): Pubic warehouse system and warehouse receipts, questionnaire, authors' internal documentation, Belgrade, Serbia.

9. Mahanta, D. (2012): Review of warehouse receipt as an instrument for financing in India, International Journal of Scientific \& Technology Research, Vol. 1, No. 9, pp. $42-45$.

10. Mirović V., Bolesnikov, D. (2013): Application of asset securitization in financing agriculture in Serbia, Economics of Agriculture, Vol. 60, No. 3, p. 551-564.

11. Mor, N., Fernandes, K. (2009): Warehouse receipt finance for farmers: A glimpse, Commodity insight - Yearbook 2009, Experts' views, MCX and PricewaterhouseCoopers (PwC), Mumbai, India, pp. 42-47, available at: http://marathi.mcxindia.com/ knowledgehub/commoditybook/PDF/CI_Article5.pdf accessed: 30.5.2015.

12. Shamos, M. I. (2004). Paper v. electronic voting records-an assessment, online proceedings, $14^{\text {th }}$ ACM Conference on Computers, Freedom and Privacy, Berkeley, USA, available at: http://www.cfp2004.org/cfp2004/program/materials/p12-shamos.pdf

13. The law on public warehouses for agricultural products, Official Gazette of the Republic of Serbia, No. 41/09.

14. USAID (2002): Regional commodity exchange initiative, phase 1, Vol. 2, ACDI/VOCAUSAID, Belgrade, Serbia.

15.USAID (2011): Dematerialization of warehouse receipts in the commodity markets, report, USAID business enabling project, USAID, Washington, DC, p. 7, available at: www.policycafe.rs/documents/financial/research-and-publications/commodity-marketdevelopment/paper-on-warehouse-receipts-and-dematerialization.pdf, accessed: 15.4.2015.

16. Varangis, P., Larson, D.(1996): How warehouse receipts help commodity trading and financing, report, Dec-notes, No. 21 (September 1996), report No. 17856, World Bank, Washington DC, USA, p. 4, available at: http://documents.worldbank.org/curated/en/1996/09/438898/ warehouse-receipts-help-commodity-trading-financing, accessed: 5.10.2015.

17. Vasiljević, Z., Zakić, V. (2006): Finansiranje agroprivrede Srbije u uslovima tranzicije, Ekonomski vidici, Vol. 11, No. 2, p. 341-352.

18. Vasiljević, Z., Zakić, V., Bojčevski, M., Kovačević, V. (2014): Importance of Establishing the Agricultural Products Storage System for Third Parties in the Function of Agribusiness System Improvement, proceedings, $9^{\text {th }}$ International conference - The Role of Agricultural Economic Sciences in Agriculture and Rural Development in the Balkan Countries, Association of Agricultural Economists of Republic of Macedonia (AAEM), 24-25 ${ }^{\text {th }}$ April 2014, Ohrid, Macedonia, p. 317-332.

19.Zakić, V., Kovačević, V. (2012): Importance of commodity derivatives for Serbian agricultural enterprises risk management, Proceedings, International Scientific Meeting Sustainable agriculture and rural development in terms of the Republic of Serbia strategic goals realization within the Danube Region, Tara, 6- $8^{\text {th }}$ December, 2012, IAE, Belgrade, pp. 907-924.

20.Zakić, V., Kovačević, V., Ivkov, I., Mirović, V., (2014): Importance of public warehouse system for financing agribusiness sector, Economics of Agriculture, Vol. 61, No. 4, pp. 
929-943.

\title{
ELEKTRONSKI REGISTAR ROBNIH ZAPISA KAO KORAK OD PAPIRNOG KA ELEKTORNSKOM ROBNOM ZAPSIU
}

\author{
Vlado Kovačević11, Vladimir Zakič12, Miloš Milovanovićn ${ }^{13}$, Jonel Subićc ${ }^{14}$, \\ Marko Jeločnik ${ }^{15}$
}

\section{Sažetak}

Cilj ovog rada je da se utvrdi ekonomska opravdanost uvođenja elektronske evdencije robnog zapisa, kao koraka ka uvođenju u potpunosti elektronskog robnog zapisa.

Obe forme robnog zapisa postoje u praksi, ali je papirni oblik robnog zapisa više u upotrebi. U ovom radu proces dematerijalizacije je analiziran u dva koraka. Prvi je dematerijalizacija knjige robnih zapisa, dok je robni zapis u papirnoj formi. Drugi korak je uvođenje potpunog sistema elektornskog robnog zapisa.

Dematerijalizacija robnog zapisa je kompleksnija u odnosu na dematerilalizaciju efektnih hartija od vrednosti zbog individualnih karakteristika svakog robnog zapisa. Kao rezulatat ovoga, elektronski sistemi robnih zapisa su retki u svetu i u primeni su za samo nekoliko vrsta roba, poput pamuka i nekoliko vrsta žitarica. Ipak promena od papirnih hartija od vrenosti ka elektronskim u finansijskom sektoru, koja je počela pre nekoliko decenija, sada se intenzivira i u oblasti poljoprivrednih proizvoda.

Analize u ovom radu pokazuju značajan uticaj elektronske evidencije robnih zapisa na povećanje sigurnosti sisetema javnih skladišta i unapređenje trgovanja robnim zapisima.

Ključne reči: robne berze, javna skladišta, elektronski robni zapi, kratkoročni krediti

11 Dr Vlado Kovačević, naučni saradnik, savetnik ministra, Ministarstvo poljoprivrede i zaštite životne sredine Republike Srbije, Nemanjina 22-26, 11000 Beograd, Srbija, Telefon: +381 6465 81 519, E-mail: vlado.kovacevic@minpolj.gov.rs

12 Docent, dr Vladimir Zakić, Univerzitet u Beogradu, Poljoprivredni fakultet, Nemanjina 6, 11080 Zemun, Srbija, Telefon: +381 63313 234, E-mail: zakic@agrif.bg.ac.rs

13 Miloš Milovanović, M.Sc., Koordinator za FAO-EBRD projekte u Republici Srbiji, Todora Dukina 29, 11000 Beograd, Telefon: +381 6482356 28, E-mail: milos.milovanovic@,fao.org

14 Profesor, dr Jonel Subić, viši naučni saradnik, Institut za ekonomiku poljoprivrede, Volgina 15, 11060 Beograd, Srbija, Telefon: +381 63296 111, E-mail: jonel s@iep.bg.ac.rs

15 Marko Jeločnik, M.A., istraživač saradnik, Institut za ekonomiku poljoprivrede, Volgina 15, 11060 Beograd, Srbija, Telefon: +381 116972 858, E-mail: marko_j@iep.bg.ac.rs

EP 2016 (63) 3 (801-815) 